\title{
PERAN BANK SYARIAH MANDIRI DALAM MENGEMBANGKAN WISATA HALAL
}

\author{
Inayatillah Djakfar ${ }^{1}$, Isnaliana ${ }^{2}$, Yossie Kenanga Putri ${ }^{3}$ \\ 1,2,3 Universitas Islam Negeri Ar-Raniry, Banda Aceh, Indonesia
}

$\bowtie$ Corresponding Author:

Nama Penulis: Inayatillah Djakfar

E-mail:inayatillah.djakfar@ar-raniry.ac.id

\section{Abstract}

This study aims to see the role of Bank Syariah Mandiri Kcp Ulee Kareng in developing halal tourism in the city of Banda Aceh. This study uses a qualitative method using a descriptive analysis approach. This research uses primary data and secondary data, namely by conducting interviews and centering studies and documentation which is analyzed in several stages, namely editing data, classifying, reducing, presenting data, and finally verifying. The results showed that Bank Syariah Mandiri Kcp Ulee Kareng has a role in developing halal tourism, namely in the Culinary Business Sector, Travel Service Providers and Lodging Providers. The financing provided to business actors is the financing of Micro Businesses. With the financing provided by this institution to players in the halal tourism industry, it has an impact on improving the economic welfare of the people.

Keywords: Halal Tourism; Islamic Banking; Financing Micro Business

\section{Abstrak}

Penelitian ini bertujuan untuk melihat Peran Bank Syariah Mandiri KCP Ulee Kareng dalam mengembangkan wisata halal di Kota Banda Aceh. Penelitian ini menggunakan metode kualitatif dengan menggunakan pendekatan deskriptif analisis. Penelitian ini menggunakan data primer dan data sekunder, yaitu dengan melakukan wawancara dan studi kepustakaan serta dokumentasi yang dianalisis dengan beberapa tahapan yaitu mengedit data, mengklasifikasi, mereduksi, lalu menyajikan data, dan akhirnya melakukan verifikasi. Hasil penelitian menunjukkan bahwa Bank Syariah Mandiri KCP Ulee kareng memiliki peran dalam mengembangkan wisata halal yakni pada Sektor Usaha Kuliner, Penyedia Jasa Travel dan Penyedia Penginapan. Adapun pembiayaan yang diberikan kepada para pelaku usaha ialah pembiayaan Usaha Mikro. Dengan adanya pembiayaan yang diberikan oleh lembaga tersebut kepada para pelaku industri pariwisata halal berdampak bagi peningkatan kesejahteraan ekonomi umat.

Kata kunci: Wisata Halal, Bank Syariah, Pembiayaan Usaha Mikro

\section{PENDAHULUAN}

Istilah Wisata Halal mulai dikenal sejak Tahun 2015 ketika sebuah event World Halal Tourism Summit (WHTS) digelar di Abu Dhabi, Uni Emirat 
Arab. Sebelumnya dunia pariwisata hanya mengenal sebagai muslim tour atau semisalnya. Dalam event ini WHTS berusaha menyadarkan bahwa pangsa pasar dari wisata halal sangatlah besar, hal ini dapat dilihat dari prediksi WHTS pada tahun 2019 yakni tidak kurang dari 238 milyar USD berputar di dunia wisata halal (di luar haji dan umrah), ini artinya pertumbuhan dunia wisata halal melejit hampir mendekati 90\% lebih cepat daripada wisata umum dari tahun ke tahun. Lebih hebatnya, jumlah tumbuh dari waktu ke waktu. Pelayanan wisatawan dalam pariwisata halal merujuk pada aturan-aturan Islam (Disbudpar Aceh, 2016).

Pengembangan wisata halal menjadi alternatif bagi industri wisata di Indonesia seiring dengan tren wisata halal yang menjadi bagian dari industri ekonomi Islam global. Salah satu contoh dari bentuk pelayanan wisata halal ini misalnya hotel yang tidak menyediakan makanan ataupun minuman yang mengandung alkohol dan memiliki kolam renang serta fasilitas spa yang terpisah untuk pria dan wanita. Selain hotel, transportasi dalam industri pariwisata halal juga memakai konsep Islami. Penyedia jasa transportasi wajib memberikan kemudahan bagi wisatawan muslim dalam pelaksanaan ibadah selama perjalanan. Kemudahan ini bisa berupa penyediaan tempat sholat di dalam pesawat, pemberitahuan berupa pengumuman maupun adzan jika telah memasuki waktu sholat selain tentunya tidak adanya makanan atau minuman yang mengandung alkohol dan adanya hiburan Islami selama perjalalanan (Disbudpar Aceh, 2016).

Mayoritas literatur dan kajian studi lapangan tentang kepariwisataan menunjukan bahwa pengembangan pariwisata pada suatu daerah mampu memberikan dampak ekonomi seperti peningkatan pendapatan masyarakat, peningkatan penerimaan devisa, peningkatan kesempatan kerja dan peluang usaha, peningkatan pendapatan pemerintah dari pajak dan keuntungan badan usaha milik pemerintah, menjaga kelestarian alam dan sebagainya. Dapat disadari pentingnya industri pariwisata terhadap perekonomian Indonesia dikarenakan pertumbuhan pariwisata Indonesia selalu di atas pertumbuhan ekonomi Indonesia (Soebagyo, 2012).

Begitu halnya dengan Aceh, Aceh yang terkenal dengan Serambi Mekkah dan menerapkan syariat Islam tidak mau ketinggalan untuk pengembangan wisata halal. Aceh juga memiliki sumber daya yang menjanjikan untuk mengembangkan wisata halal atau syariah. Hal ini dikarenakan latar belakang budaya Aceh yang kental dengan nilai-nilai keIslaman. Wisata halal memiliki cakupan yang luas. Mulai dari makanan halal hingga tingkat pelayanan dan fasilitas yang disediakan untuk wisatawan muslim. berbagai sektor seperti perhotelan, rumah makan, sarana transportasi, dan lain-lain. Pemerintah, pihak swasta dan masyarakat merupakan element penting dalam pembangunan yang harus bersinergi 
untuk mewujudkan wisata halal. Wisata halal harus dipahami secara baik oleh ketiga pihak tersebut, untuk itu dibutuhkan sosialisasi yang benar mengenai halal tourism (Firdhaus, 2018).

Begitu pula dengan Banda Aceh, menurut Kepala Dinas Kebudayaan dan Pariwisata Aceh, Jamaludin mengatakan bahwa pada tahun 2019 wisatawan yang datang ke Aceh bisa mencapai 2,6 juta orang, target itu lebih tinggi dari tahun 2018 yang mencapai 2,4 juta lebih. Salah satu target dinas pariwisata dengan peningkatan layanan kepada tamu, termasuk membuka objek-objek wisata baru dan pengembangan lokasi wisata (Redaksi, 2019).

Selain itu keterlibatan Lembaga Keuangan Syariah terutama Perbankan Syariah juga menjadi bagian yang paling penting dari sistem pengembangan pariwisata halal di kota Banda Aceh. Hal ini disebabkan oleh mayoritas masyarakat kota Banda Aceh 99,99\% yang beragama Islam. Sehingga kehadiran lembaga ini dapat mendongkrak para pelaku pariwisata untuk mengembangkan usahanya melalui pembiayaan yang di tawarkan. Sebagai bagian dari sistem keuangan Islam yang paling maju, bank syariah juga menunjukkan eksistensinya. Hal ini dibuktikan dengan $80 \%$ asset dari industri keuangan syariah global adalah perbankan syariah (Serambinews, 2017).

Berdasarkan Tabel 1. dapat diketahui bahwa keuangan syariah secara global memiliki market share hanya sekitar 1 persen. Sedangkan sektor riil (fesyen, obat-obatan dan kosmetik) masing-masing 12 persen. Kemudian untuk makanan mencapai 17 sampai 18 persen. Industri perbankan syariah di Indonesia memiliki market share 5 persen dari total industri keuangan Indonesia. Dan industri pariwisata halal sebanyak 11 persen dari pariwisata biasa. Perbedaan market share yang besar antara industri perbankan syariah dan industri sektor riil (yang dapat dijadikan indutsri halal) merupakan bentuk permasalahan yang dihadapi Indonesia saat ini (Wulandari, 2019). Maka, sudah seharusnya perbankan syariah melihat ini sebagai peluang pengembangan industri halal.

Tabel 1. Market Share Transaksi Syariah

\begin{tabular}{lll}
\hline No & Market Share & Persentase \\
\hline 1. & Keuangan Syariah secara Global & $1 \%$ \\
\hline 2. & $\begin{array}{l}\text { Sektor Riil (fesyen,obat-obatan, dan } \\
\text { kosmetik) }\end{array}$ & $12 \%$ \\
\hline 3. & Makanan & $17 \%-18 \%$ \\
\hline 4. & Perbankan Syariah & $5 \%$ \\
\hline 5. & Pariwisata Halal & $11 \%$ \\
\hline
\end{tabular}

Sumber : Yustati \& Handayani (2017)

Untuk itu perlunya upaya serius dari berbagai pemangku kepentingan, baik dari pemerintah, perbankan serta pelaku usaha. Salah satu pendekatan 
yang umum dalam memasarkan perbankan syariah, yakni melalui pendekatan produk yang dikemas dengan paket yang terbilang selalu laris, yakni haji dan umrah. Metode lain yaitu melalui pendekatan dengan para pelaku usaha atau UMKM (Yustati \& Handayani, 2017).

Menurut Ketua Asosiasi Perbankan Syariah Indonesia (Abisindo Aceh), Haizir Sulaiman mengatakan bahwa perbankan syariah di Aceh meningkat menjadi 50 persen. Untuk itu Bank Syariah menjadi sorotan publik, terutama terkait pendanaan, pembiayaan dan penyaluran kepada masyarakat (Serambinews, 2017). Mengenai sistem pembiayaan, perbankan syariah tentunya memiliki dampak yang besar terhadap perkembangan dan pertumbuhan dalam sektor riil. Salah satunya adalah dengan cara mendorong unit-unit usaha mikro kecil dan menengah, karena unit-unit usaha tersebut memiliki posisi yang begitu penting dalam perekonomian nasional.

Perbankan syariah memiliki potensi yang sangat besar dalam perekonomian. Sistem perbankan syariah ini sangat cocok untuk mengembangkan UMKM yang memiliki peran strategis dalam menggerakkan ekonomi nasional. Dengan demikian, kontribusi perbankan syariah dalam pengembangan UMKM sangat diharapkan dapat berjalan dengan lebih maksimal. Salah satu contohnya adalah dengan meningkatkan aksebilitas dengan pembiayaan yaitu memberikan persyaratan yang lebih mudah serta dilakukannya pelatihan dan pendampingan usaha (Kompasiana, 2017).

Bank Syariah Mandiri (BSM) KCP Ulee Kareng merupakan salah satu bank yang memiliki Pangsa Pasar yang sangat besar dikarenakan kawasan tersebut merupakan salah satu kawasan yang berkembang dan juga menjadi pusat pasar di kawasan kota Banda Aceh, kehadiran BSM di Ulee Kareng sebagai suatu peluang untuk pengembangan Usaha Mikro Kecil Menengah sehingga masyarakat dapat mengakses modal usaha lebih dekat. Kawasan Ulee Kareng juga terdapat banyak para pelaku usaha yang dapat menjadi mitra kerja BSM, sehingga masyarakat di sekitar Ulee Kareng dapat terbantu dalam permodalan pengembangan usahanya. Berdasarkan dari uraian di atas Bank Syariah tentunya memiliki peran besar dalam mengembangkan Wisata Halal di kota Banda Aceh, sehingga diperlukan penelahaan yang lebih mendalam mengenai peran Bank Syariah Mandiri KCP Ulee Kareng dalam pengembangan wisata halal.

\section{KAJIAN PUSTAKA}

Kepariwisataan adalah suatu aktivitas manusia yang dilakukan secara sadar yang mendapat pelayanan secara bergantian diantara orang-orang dari daerah lain untuk sementara waktu mencari kepuasaan yang beraneka 
ragam dan berbeda dengan apa yang di alaminya, dimana ia memperoleh pekerjaan tetap (Sedarmayanti, 2013).

Implementasi Wisata Halal di Aceh terdapat dalam Qanun Aceh No.8 Tahun 2013 tentang Kepariwisataan. Penyelenggaraan kepariwisataan dilaksanakan dengan tetap memelihara kelestarian dan mendorong upaya peningkatan mutu lingkungan hidup serta objek dan daya tarik wisata itu sendiri, nilai-nilai budaya bangsa yang menuju kearah kemajuan adab, mempertinggi derajat kemanusiaan, kesusilaan dan ketertiban umum guna memperkukuh jati diri bangsa dalam rangka perwujudan keutuhan bangsa.

Pembangunan pariwisata merupakan salah satu sektor pembangunan di bidang ekonomi yang dapat mempercepat pertumbuhan ekonomi dan kesejahteraan masyarakat. Badan Perencanaan Nasional Indonesia (Bappenas) dalam Visi dan Arah Pembangunan Jangka Panjang (PJP) tahun 2005-2025 menuliskan bahwa: Kepariwisataan dikembangkan agar mampu mendorong kegiatan ekonomi dan meningkatkan citra Indonesia, meningkatkan kesejahteraan masyarakat lokal, serta memberikan perluasan kesempatan kerja. Pengembangan kepariwisataan memanfaatkan keragaman pesona keindahan alam dan potensi nasional sebagai wilayah wisata bahari terluas di dunia secara arif dan berkelanjutan, serta mendorong kegiatan ekonomi yang terkait dengan pengembangan budaya bangsa.

Berkaitan dengan perkembangan kepariwisataan, Sunaryo (2013) dan berpandangan bahwa pembangunan pariwisata bertitik tolak pada empat pilar yaitu; destinasi, pemasaran (promosi), industri pariwisata dan kelembagaan. Keempat pilar pembangunan pariwisata tersebut akan menjadi pedoman dasar dalam penyelenggaraan pembangunan di bidang kepariwisataan.

Dari keempat pilar tersebut salah satunya yakni pilar kelembagaan, dimana peran kelembagaan atau lembaga terutama lembaga keuangan syariah atau yang lebih spesifiknya perbankan syariah. Dimana perbankan syariah dapat memberikan pembiayaan terhadap pelaku usaha atau penyedia pariwisata. Bank syariah menyediakan beberapa produk pembiayaan untuk mengembangkan pariwisata tersebut, yakni produk pembiayaan mudharabah, murabahah, musyarakah dan ijarah. Melalui keempat produk tersebut bisa menjadi alternatif bagi para pelaku UMKM wisata halal untuk mengembangkan usahanya.

Menurut Sidharta (2017), dan Novitasari (2019) dalam penelitiannya yang terkait Peran Perbankan Syariah dalam Mendukung Wisata Halal menunjukkan bahwa kondisi bank syariah dalam mendukung wisata halal belum melakukan sosialisasi yang efektif kepada para pelaku industri wisata. Salah satunya akses kantor dan jaringan atm yang masih sulit ditemui serta kurangnya promosi yang dilakukan oleh perbankan syariah. Sementara, 
potensi bank syariah itu sendiri dapat melakukan inovasi produk dengan memberikan kekhususan produk pembiayaan bagi para pelaku industri wisata. Perbankan syariah juga perlu melakukan event yang menarik agar dapat merubah pola pikir masyarakat bahwa bank syariah merupakan bank yang inklusif bukan ekslusif.

Penelitian yang dilakukan oleh Fauzi et.al (2018), dan Sterren (2008) menunjukan bahwa peran lembaga keuangan syariah sejauh ini dapat dilihat dari pembiayaan yang diberikan industri pariwisata, penyediaan produk bagi pelaku wisata maupun keikutsertaan event-event yang diadakan oleh dinas pariwisata dalam bentuk Sponsorship. Peran hotel dalam meningkatkan potensi wisata halal dilakukan dalam bentuk penyediaan akomodasi yang sesuai dengan standar syariah yang mencakup aspek produk, pelayanan maupun pengelolaannya. Dalam hal standar syariah belum terpenuhi, akomodasi paling sedikit memuat ketersediaan fasilitas yang layak untuk bersuci, fasilitas yang memudahkan untuk beribadah, makanan dan minuman yang halal. Hotel juga ikut andil mempromosikan branding lombok sebagai wisata halal dunia kepada para wisatawan lokal maupun mancanegara.

Yustati \& Handayani (2017), Sriprasert (2014), dan Ilyas (2017) dalam hasil penelitiannya menunjukkan bahwa, dari berbagai literatur yang ditemui untuk memberikan solusi-solusi bagaimana starategi yang dapat diterapkan oleh perbankan syariah dalam pengembangan industri halal di Indonesia. Indonesia merupakan sebuah negara dengan mayoritas muslim terbesar di dunia. Muslim adalah sebuah pasar potensial dalam pengembangan industri halal saat ini. Karena Islam mengatur setiap aspek kehidupan manusia terutama dari sektor konsumsi. Konsumsi secara luasnya di definisikan sebagai manfaat setiap produk.

Ada empat sektor penting dimana kesempatan besar dalam pengembangan industri halal yaitu: industri makanan, industri farmasi, industri fesyen, dan industri pariwisata. Perbankan syariah dapat memiliki peraturan dalam membangun keempat sektor tersebut, termasuk kerja sama dengan perusahaan-perusahaan yang akan mengeluarkan produk-produk dengan label halal dan secara keuangan menggunakan perbankan syariah. Perbankan syariah dapat menghasilkan kartu debit syariah dan kartu syariah untuk memfasilitasi para turis agar dapat mengakses pariwisata halal. Perbankan syariah dapat memberikan pembiayaan kepada pengusahapengusaha dalam bidang pariwisata halal, fesyen dan produk farmasi untuk membangun bisnis mereka yang nantinya dapat membantu meningkatkan industri halal.

Sungkawaningrum \& Nasrullah (2019), dan Muhammad (2019) menyatakan bahwa, perbankan syariah memiliki peranan yang besar dalam mengembangkan industri halal di Indonesia. Bukan hanya perbankan 
syariah yang akan tumbuh, namun pertumbuhan ekonomi di Indonesia juga akan tumbuh dan berkembang. Industri halal yang berpeluang tumbuh pesat diantaranya industri makanan dan minuman, industri obat-obatan, industri kosmetik, industri fesyen, dan industri pariwisata. Perlu adanya kerjasama dengan perusahaan yang berkecimpung di industri tersebut untuk menggunakan produk perbankan yang sesuai syariah.

Setiawan (2020) melakukan penelitian yang berjudul Optimalisasi Peran Perbankan Syariah Dalam Mengembangkan Industri Halal (Studi Pada Industri Fesyen Busana Muslim di Provinsi Lampung). Hasil penelitian menunjukkan bahwa, perbankan syariah dalam mengembangkan industri halal sudah cukup baik. Hal ini ditunjukkan dengan adanya sosialisasi melalui event-event kepada para pelaku industri halal fesyen di Provinsi Lampung.

\section{METODE}

Jenis penelitian ini adalah kualitatif dengan menggunakan metode deskriptif analitis. Penulis menggunakan cara mendeskripsikan peran Bank Syariah Mandiri dalam mengembangkan wisata halal di kota Banda Aceh. Penelitian ini dilakukan di PT. Bank Syariah Mandiri KCP Ulee Kareng. Alasan pemilihan PT. Bank Syariah Mandiri KCP Ulee Kareng yaitu; pertama, sebagai salah satu bank yang mendukung pariwisata halal di Aceh yang dibuktikan dengan adanya penyediakan pembiayaan kepada pelaku industri wisata halal, kedua, terletak dipusat kota Banda Aceh. Kemudian informan dalam penelitian ini terdiri dari pihak Bank Syariah Mandiri, tokoh, pegiat wisata halal di Aceh, Disbudpar Aceh, Pelaku UMKM, Pemilik Travel, Pemilik homestay, dan lainnya. Penelitian ini menggunakan data primer dan data sekunder, yaitu dengan melakukan wawancara dan studi kepustakaan serta dokumentasi yang dianalisis dengan beberapa tahapan yaitu mengedit data, mengklasifikasi, mereduksi, lalu menyajikan data, dan akhirnya melakukan verifikasi.

\section{HASIL DAN PEMBAHASAN}

Peran bank syariah di Kota Banda Aceh sejauh ini dapat dilihat dari pembiayaan yang diberikan kepada industri pariwisata, penyediaan produk bagi pelaku wisata maupun keikutsertaan dalam event-event yang diadakan oleh Dinas Pariwisata dalam bentuk sponsorship. Peran hotel untuk meningkatkan potensi wisata halal dilakukan dalam bentuk penyediaan akomodasi yang sesuai dengan standar syariah yang mencakup aspek produk, pelayanan maupun pengelolaannya. Dalam hal standar syariah belum terpenuhi, akomodasi paling sedikit memuat ketersediaan fasilitas yang layak untuk bersuci, fasilitas yang memudahkan untuk beribadah, 
makanan dan minuman yang halal. Hotel juga ikut andil mempromosikan branding Aceh sebagai wisata halal dunia kepada para wisatawan lokal maupun mancanegara.

Berdasarkan dimensi peran, Bank syariah memiliki peran diantaranya sebagai pemangku kebijakan, karena merupakan pilihan yang tepat untuk mengembangkan industri pariwisata; dan mendapatkan keuntungan finansial dari penyaluran dana modalnya. Bank syariah dalam penyaluran dana juga berperan sebagai strategi karena selain mendukung industri pariwisata masyarakat di kota Banda Aceh namun juga menarik kepercayaan dan dukungan sehingga memunculkan loyalitas masyarakat dalam mengambil pembiayaan di bank syariah.

Selanjutnya, dalam hal penyaluran dana bank syariah juga berperan sebagai alat komunikasi karena memiliki alat atau instrument dalam bentuk informasi produk dan layanan yang mampu mempengaruhi sudut pandang dan preferensi masyarakat dalam menentukan alternatif pembiayaan modal bagi pengembangan usaha pelaku pariwisata. Bank syariah dalam penyaluran dana kepada para pelaku industri pariwisata halal juga berperan sebagai alat penyelesaian sengketa yakni sebagai alternatif pembiayaan bagi para pelaku usaha yang memiliki kendala modal dalam mengembangkan usahanya. Secara tidak langsung, peran bank syariah dalam mengembangkan industri pariwisata telah mencakup keseluruhan dimensi peran.

Jika dikaitkan dengan peran pokok bank syariah dalam tinjauan berbagai aspek, bank syariah dalam pengembangan pariwisata halal berperan sebagai pemberdaya ekonomi umat. Hal ini bertujuan untuk menyalurkan dana kepada para pelaku industri. Sehingga, para pelaku industri pariwisata dapat berkembang dan berdaya dalam meningkatkan kesejahteraan ekonominya.

\section{Pandangan Perbankan Syariah Terhadap Peluang Usaha Wisata Halal}

Banda Aceh merupakan gerbang wisata halal di provinsi Aceh yang juga merupakan Ibukota provinsi Aceh. Masjid Raya Baiturrahman sebagai icon wisata halal memiliki daya tarik tersendiri bagi para wisatawan. Hal ini menjadi prospek positif bagi para pelaku industri halal dan para investor guna mengembangkan wisata halal di Aceh dan Indonesia. Dalam sebuah wawancara dengan pihak Bank Syariah Mandiri (BSM) KCP Ulee Kareng mengemukakan bahwa:

"wisata halal merupakan peluang usaha yang bagus di Banda Aceh. Di mana, dengan adanya masjid raya baiturrahman menjadi dari Tarik lebih bagi para wisatawan baik dari dalam negeri maupun mancanegara untuk berkunjung ke Aceh. Hal ini akan meningkatkan perkembangan wisata halal di Aceh." (hasil wawancara dengan pihak Bank Syariah Mandiri (BSM) KCP Ulee Kareng). 
Dalam hal ini Aceh yang merupakan daerah yang menjunjung tinggi syariat Islam menjadi modal penting bagi pemerintah, pelaku industri halal, investor, dan khususnya perbankan untuk menjadi penyedia dana bagi para pelaku industri halal. Dengan adanya modal bagi para pelaku industri dapat menopang perkembangan wisata halal di Aceh khususnya kota Banda Aceh.

Menurut pengamatan oleh pihak Bank Syariah Mandiri (BSM) KCP Ulee Kareng terdapat beberapa fokus yang menjadi pendukung wisata halal di Aceh yakni: sektor usaha kuliner, sektor penyedia penginapan, sektor jasa travel. Ketiga sektor tersebut menjadi segmentasi bagi pihak Bank Syariah Mandiri (BSM) KCP Ulee Kareng untuk berkontribusi terhadap perkembangan wisata halal di Aceh. Kontribusi tersebut menjadi stimulus untuk mendanai sektor wisata halal sehingga modal dan tata kelolanya sesuai dengan ketentuan syariat Islam. Dimana, wisata halal merupakan salah satu sektor penopang ekonomi menghadirkan pendapatan yang lebih kepada masyarakat yang memiliki minat bergerak di industri pariwisata halal.

Meskipun dalam beberapa waktu ini perkembangan wisata halal menjadi lambat akibat keterbatasan kunjungan sejak adanya wabah COVID19. Dalam menyikapi perlambatan tersebut pihak Bank Syariah Mandiri (BSM) KCP Ulee Kareng berusaha menyesuaikan diri dengan kondisi tersebut dengan terus mendukung perkembangan wisata halal di Aceh. Bank Syariah Mandiri (BSM) KCP Ulee Kareng menyediakan produk pembiayaan yang dapat di akses oleh para pelaku usaha yakni:

"untuk menjangkau para pelaku usaha industri wisata halal, Bank Syariah Mandiri (BSM) KCP Ulee Kareng meluncurkan beberapa produk yang terangkum dalam dua garis besar yakni pendanaan dan pembiyaan. Di mana, pendanaan yang dilakukan oleh Bank Syariah Mandiri (BSM) KCP Ulee Kareng memanfaatkan fasilitas teknologi yang dinamai Mandiri Syariah Mobile dengan tujuan dapat dengan mudah menjangkau dan diakses oleh masyarakat. Selanjutnya, untuk produk pembiayaan Bank Syariah Mandiri (BSM) KCP Ulee Kareng menawarkan produk Mikro Banking yang khusus disalurkan untuk pembiayaan UMKM semisal homestay (penginapan), usaha kuliner dan usaha pendukung wisata halal lainnya." (hasil wawancara dengan pihak Bank Syariah Mandiri (BSM) KCP Ulee Kareng)

Pemanfaatan teknologi dimasa pandemi COVID-19 ini dinilai sangat berpengaruh positif bagi masyarakat untuk tetap produktif. Hal ini dinilai sangat tepat oleh Bank Syariah Mandiri (BSM) KCP Ulee Kareng untuk menjangkau dan memberikan layanan kepada masyarakat baik nasabah dan para pelaku usaha wisata halal. Adanya pembiayaan mikro banking menjadi keutamaan tersendiri bagi para pelaku usaha UMKM untuk mengambil pembiyaan pada Bank Syariah Mandiri (BSM) KCP Ulee Kareng. 
Adanya industri pariwisata halal menjadikan sektor pembiayaan yang dilakukan oleh bank syariah berpeluang untuk fokus menjangkau industri wisata halal. Menyikapi peluang dan tantangan ini Bank Syariah Mandiri (BSM) KCP Ulee Kareng mengemukakan bahwa:

"Peluang sektor pariwisata halal di Aceh sangat besar. Hal ini dapat di lihat pada pelaku kuliner sangat luas dan dari kebutuhan akan hunian untuk wisatawan sangat tinggi. Selain itu, kondisi sektor wisata lancar dapat pula di lihat dari tumbuhnya travel yang memfasilitasi wisatawan untuk menikmati kuliner-kuliner yang ada di kota Banda Aceh dan juga menggunakan fasilitas homestay atau hotel-hotel yang menerapkan konsep syariah yang ada di kota Banda Aceh. Adapun tantangannya para pelaku usaha rata-rata belum teredukasi untuk membuat pembukuan usaha yang baik, ini menjadi tantangan sendiri akhirnya Bank Syariah Mandiri (BSM) KCP Ulee Kareng punya peluang untuk mengedukasi para pelaku usaha untuk membuat pembukuan usaha yang baik." (hasil wawancara dengan pihak Bank Syariah Mandiri (BSM) KCP Ulee Kareng)

Tantangan yang dihadapi Bank Syariah Mandiri (BSM) KCP Ulee Kareng hampir sama dengan tantangan yang dihadapi oleh industri perbankan syariah lainnya. Dimana, dana yang disalurkan oleh bank syariah dinilai tidak digunakan secara baik. Pembukuan serta perlakuan akuntansinya pun masih dirasa kurang baik. Hal ini menyebabkan arus kas nasabah pelaku industri wisata halal menjadi tidak teratur dan sistematis. Sehingga, jika terjadi keuntungan dan kerugian pihak bank sulit untuk mengidentifikasi keberlangsungan modal usaha yang dapat menyebabkan gagal bayar atau kredit macet yang dapat merugikan bank dan nasabah.

Bank Syariah Mandiri (BSM) KCP Ulee Kareng tidak sendiri memainkan peran dalam peningkatan perkembangan industri wisata halal. Terdapat banyak bank dan lembaga-lembaga pembiayaan yang berlombalomba dalam meningkatkan minat nasabah untuk mengambil pembiayaan. Menyikapi hal ini pihak Bank Syariah Mandiri (BSM) KCP Ulee Kareng mengemukakan bahwa:

"Strategi Bank Syariah Mandiri (BSM) KCP Ulee Kareng dalam menghadapi bank pesaing salah satunya dengan meningkatkan teknologi layanan yang terdapat dalam fitur MSM (Mobile Syariah Mandiri). Terdapat banyak fitur-fitur dalam Syariah Mandiri Mobile yang merupakan bentuk layanan yang dapat diakses kapanpun. Kemudian terdapat pula pendekatan aspek religi terhadap konvensional dengan payung hukum UU Otonomi daerah atau pelaksanaan syariat Islam dan UU Pemerintahan Aceh menjadi payung hukum menjadi lahirnya QANUN LKS No. 11 tahun 2018 ini sangat mendukung Bank Syariah Mandiri (BSM) KCP Ulee Kareng menjalankan bisnisnya dan berhadapan dengan pesaing-pesaing bank konvensioal 
sehingga Bank Syariah Mandiri (BSM) KCP Ulee Kareng bisa merangkul para pelaku UMKM untuk memiliki konsep pariwisata halal." (hasil wawancara dengan pihak Bank Syariah Mandiri (BSM) KCP Ulee Kareng)

Perkembangan teknologi informasi menjadi keunggulan bersaing bagi industri perbankan untuk menyajikan layanan tanpa bertatap muka di bank. Hal ini menjadi strategi dengan biaya rendah yang dapat diakses kapan saja dan dimana saja oleh nasabah. Layanan Syariah Mandiri Mobile merupakan strategi yang paling efisien dan efektif dalam menjangkau, melayani, dan mempromosikan kepada nasabah. Selain itu, faktor regulasi yang baik juga menjadi penguat legalitas perbankan syariah di Aceh. Kekhususan industri perbankan syariah menjadi nilai lebih bagi Bank Syariah Mandiri (BSM) KCP Ulee Kareng untuk menjadi perbankan syariah yang unggul dan mendapatkan nilai lebih di mata masyarakat Aceh yang menjunjung pembiayaan berbasis syariah.

Dalam operasionalnya, Bank Syariah Mandiri (BSM) KCP Ulee Kareng melakukan kontrol pembiayaan Mikro Banking dengan menerapkan konsep 5C yakni:1) Character, 2) Capacity, 3) Capital, 4) Collateral, dan 5) Condition. Konsep 5C tersebut merupakan filter yang dijadikan alat untuk memverifikasi kelayakan nasabah dalam pengambilan pembiayaan. Ketika nasabah telah diverifikasi maka proses selanjutnya adalah proses pendampingan nasabah dengan melakukan komunikasi baik harian, mingguan ataupun bulanan secara konsisten. Tidak hanya itu, pemberian apresiasi juga dilakukan oleh pihak Bank Syariah Mandiri (BSM) KCP Ulee Kareng kepada nasabah yang memiliki kondisi usaha lancar dengan kemudahan akses pembiayaan dan special price yang meliputi pembayaran multiguna dengan menggunakan fitur MSM (Mobile Syariah Mandiri).

\section{Pandangan Terhadap Perbankan Syariah Dan Keterkaitannya Dengan Wisata Halal}

Dalam implementasi industri wisata halal tidak terlepas dari permodalan dan pengembangan. Dalam hal ini, peran perbankan syariah menjadi promotor penting dalam permodalan dan pengembangan pariwisata halal. Berdasarkan hasil wawancara para pelaku usaha UMKM setuju bahwa perbankan syariah merupakan institusi bank yang dalam operasionalnya berfokus pada penerapan prinsip-prinsip syariah. Para pelaku usaha mempercayai bahwa dalam operasionalnya perbankan syariah terhindar dari pengambilan riba dan membuat masyarakat yakin uang yang mereka simpan dan ambil dalam bentuk pembiayaan terhindar dari unsur riba.

"Bank Syariah merupakan institusi bisnis yang beroperasi berdasarkan prinsip syariah. Disini perlu dipahami bahwa bank syariah, seperti 
organisasi bisnis lainnya, memiliki tujuan untuk memperoleh keuntungan secara optimal, namun dengan memperhatikan kaedah dan etika bisnis menurut syariah Islam." (hasil wawancara dengan pemilik home stay)

Penerapan nilai-nilai syariah dalam menjunjung etika dan kaedah menjadi pembeda bagi perbankan syariah dan perbankan konvensional selain upaya pencapaian keuntungan perusahaan. Hal ini menjadi perhatian penting bagi para pelaku perbankan syariah, masyarakat dan juga pemerintah untuk terus menyempurnakan nilai-nilai syariah sehingga dapat mengubah pandangan masyarakat luas yang telah terlebih dahulu merasa nyaman dengan pembiayaan perbankan konvensional. Perhatian penting bagi pemerintah Aceh yakni menerapkan Qanun dengan cara yang optimal sehingga dapat mengkonversikan sistem keuangan yang ada di Aceh menjadi syariah dan juga mengajak masyarakat untuk dengan sukarela menggunakan produk perbankan syariah. Sebagaimana pandangan Mie Khas Aceh mengenai perbankan syariah sebagai berikut:

"Bank syariah merupakan lembaga keuangan berbasis syariah yang saat ini sedang digencarkan oleh pemerintah Aceh. Pentingnya semua pihak untuk mendukung pertumbuhan bank syariah." (hasil wawancara dengan Mie Khas Aceh).

Perbankan syariah menurut para pakar wisata halal memiliki kesamaan pandangan dengan para pelaku usaha UMKM di mana para pakar seperti Dr. T Meldi Kesuma, S.E, M.M, Dr. Muhammad Yasir Yusuf, MA dan Disbudpar Aceh berpandangan bahwa perbankan syariah lembaga perbankan yang operasionalnya didasarkan pada prinsip-prinsip syariah.

"Bank Syariah adalah Lembaga Keuangan yang kegiatan operasional dan produknya menganut prinsip-prinsip Islam berlandaskan Al-Qur'an dan Hadits. Usaha pokok Bank Syariah diantaranya yaitu memberikan pinjaman ataupun jasa-jasa lainnya kepada nasabah sesuai dengan syariat Islam." (hasil wawancara dengan Dr. T Meldi Kesuma, S.E, M.M)

Tidak hanya operasionalnya yang berdasarkan prinsip-prinsip syariah dan berlandaskan pada hukum Islam dalam operasionalnya perbankan syariah, namun juga harus memberikan kemaslahatan bagi masyarakat khususnya masyarakat Aceh.

"Bank syariah adalah lembaga keuangan yang memastikan dirinya bergerak dalam bidang keuangan sesuai dengan nilai-nilai syariah. serta bank syariah adalah bank yanng dalam Undang-Undang 21 tahun 2008 bahwa kehadiran bank syariah ini adalah untuk mendorong sektor keuangan masyarakat, artinya kehadiran bank syariah harus memberi kemaslahatan kepada masyarakat." (hasil wawancara dengan Dr. Muhammad Yasir Yusuf, MA) 
Legalitas perbankan syariah dalam Undang-undang No. 21 tahun 2008 menjadi landasan penting setelah hukum Islam dalam operasionalnya selain mencari keuntungan namun juga menciptakan kemaslahatan umat dalam melalui sistem keuangan syariah tanpa riba. Hal ini menjadi nilai keunggulan tersendiri bagi perbankan syariah untuk lebih mengembangkan produkproduk syariah yang menarik minat para pelaku usaha UMKM khusunya pelaku industri pariwisata halal.

Mengenai keterkaitan bank syariah dan wisata halal para pakar wisata halal berbeda pandangan. Dr. T Meldi Kesuma, S.E, M.M dalam wawancara berpandangan bahwa:

"Bank Syariah tidak terlalu memiliki hubungan yang signifikan terhadap wisata halal, karena mereka merupakan lembaga yang berjalan dengan berbeda visi dan misi. Keterkaitannya tidak terlalu, namun Partisipasi bank syariah untuk mengembangkan wisata halal terutama sangat penting dalam bidang jasa, karena wisatawan itu terbagi dua yaitu wisman dan wisnus. Orang wisnus kita katakanlah mereka 50\% menggunakan bank syariah. Untuk wisatawan wisman sebagian besar nonmuslim, dan sebagian besar perbankan diluar itu masih sedikit sekali kecuali Malaysia, paling bnyak pengunjung dari Malaysia. Kita tidak bisa mengganti bahwa perbankan syariah digunakan oleh wisman dan wisnus" (hasil wawancara dengan Dr. T Meldi Kesuma, S.E, M.M)

Pendapat tersebut dinilai sangat sesuai dengan asumsi bahwa tidak semua para wisatawan yang datang ke Aceh adalah Muslim. Hal ini berkaitan dengan kegiatan yang dilakukan oleh para wisatawan saat bertransaksi secara non-tunai ataupun tunai dengan melakukan penarikan via ATM. Dengan asumsi 50\% wisatawan nusantara yang telah menggunakan produk bank syariah menjadikan pertimbangan bahwa belum seluruhnya bank syariah mampu mengakomodasi pelayanan pada wisatawan baik itu dari sisi popularitas dan sisi kepercayaan menggunakan bank syariah dalam bertransaksi. Namun dalam kaitannya perbankan syariah terhadap pengembangan investasi Dr. T Meldi Kesuma, S.E, M.M beranggapan ini sangat penting namun untuk saat ini belum dinilai berperan signifikan. Sedangkan dalam wawancara yang lain dengan permasalahan yang sama Dr. Muhammad Yasir Yusuf, MA berpandangan bahwa:

"Ada hubungan yang sangat erat antara bank syariah dengan wisata halal yang pertama dikarenakan, perkembangan wisata halal (steakholder) wisata halal mulai dari pemerintah, masyarakat dan juga para pembisnis ketika mereka ingin mengembangkan wisata halal. Ada diantara masyarakat yang membutuhkan permodalan maka bank syariah adalah sebuah lembaga yang bisa membantu permodalan bagi masyarakat, terutama para pelaku wisata halal (travel, kuliner, 
restoran) harus mendapatkan dukungan pembiayaan dari bank syariah karena otomatis ketika bank syariah memberkan permodalan, infrastruktur wisata halal bisa berjalan dengan baik dan tentunya akan simbiosis mutualisme memberikan keuntungan bagi masyarakat itu sendiri. Sepatutnya bank syariah mendukung sektor pengembangan wisata halal, karena bukan hanya bagaimana menjadikan muslim itu menjadikan gaya hidup halal dalam wisata tapi juga memastikan bahwa tempat wisata halal ini mendapatkan dana permodalan dari lembaga keuangan syariah." (hasil wawancara dengan Dr. Muhammad Yasir Yusuf, MA).

Pandangan adanya keterkaitan antara bank syariah dan wisata halal juga didukung oleh pandangan Disbudpar Aceh yang dalam wawancara berpandangan bahwa:

"Bank syariah sangat mendukung dalan implemementasi wisata halal. Contohnya penerapan pada teman-teman di BPOM. ketika mereka menemukan suatu produk mereka juga melihat dari sisi pembiayaannnya, ketika modal dari bank konvensional mungkin akan susah untuk mendapati sertifikasi halal. Itu sangat bagus dan penting sehingga teman-teman tidak mendapatkan kendala sertifikasi halal bagi masyarakatnya. Pihak perbankan syariah juga sangat di perlukan dalam artian memberikan pemahaman yang sangat positif kepada masyarakat, kepada pengambil kebijakan dalam pengembangan pariwisata, dimana suatu lokasi wisata itu hidup/ maju otomatis ekonomi masyarakat disekitarnya juga akan maju." (hasil wawancara dengan Disbudpar Aceh).

Perbedaan pandangan ini hanya terjadi pada perbedaan indikator yang dijadikan sebagai tolak ukur keterkaitan bank syariah dan wisata halal. Pandangan Dr. Muhammad Yasir Yusuf, MA dan Disbudpar Aceh bahwa tidak hanya terdapat keterkaitan antara bank syariah dan pelaku usaha saja namun juga masyarakat dan juga pemerintah. Dalam hal ini bank syariah diharapkan dapat berkontribusi penting bagi permodalan usaha wisata halal di Aceh karena selain menjadi sumber pendanaan, namun juga sebagai pertimbangan bagi BPOM sebagai tolak ukur pemberian sertifikasi halal berdasarkan kriteria sumber pendanaan. Hal ini tentu menjadi keunggulan besar bagi perbankan syariah untuk memberikan pendanaan dalam perkembangan wisata halal. Berdasarkan penjelasan di atas peneliti menyimpulkan bahwa dari sisi pembiayaan oleh bank syariah terhadap wisata halal memiliki keterkaitan yakni mendorong pengembangan usaha wisata halal.

Selain itu, pembiayaan bank syariah terhadap pelaku usaha wisata halal dapat mempermudah akses perizinan pengurusan labelisasi halal pada BPOM dari sisi sumber pendanaan. Namun, perlu menjadi pertimbangan juga 
bagi bank syariah untuk memperhatikan pelayanan yang tidak hanya berfokus pada pembiayaan pada pelaku usaha saja, melainkan juga pada penyedian sarana dan prasarana pendukung bagi para wisatawan mancanegara (Wisman) dan wisatawan nusantara (Wisnus) sehingga para wisatawan dapat mengakses pelayanan yang disedikan oleh bank syariah.

\section{KESIMPULAN}

Berdasarkan hasil pembahasan dapat disimpulkan bahwa Bank Syariah Mandiri KCP Ulee kareng memiliki peran untuk mengembangkan wisata halal. Khususnya yaitu pada sektor usaha kuliner, penyedia jasa travel dan penyedia penginapan. Peran yang ditunjukkan yaitu melalui pembiayaan yang diberikan kepada para pelaku usaha wisata halal. Adapun pembiayaan yang diberikan oleh Bank Syariah Mandiri KCP Ulee Kareng kepada para pelaku usaha ialah pembiayan Usaha Mikro. Jika dilihat dari dimensi peran bank syariah yaitu memiliki peran diantaranya sebagai kebijakan, karena merupakan pilihan yang tepat untuk mengembangkan industri pariwisata dan mendapatkan keuntungan finansial dari penyaluran dana modalnya. Bank Syariah dalam penyaluran dana juga berperan sebagai strategi karena selain mendukung industri pariwisata masyarakat di kota Banda Aceh, juga menarik kepercayaan dan dukungan sehingga memunculkan loyalitas masyarakat dalam mengambil pembiayaan di bank syariah.

Dalam hal penyaluran dana bank syariah juga berperan sebagai alat komunikasi. Hal ini dikarenakan Bank syariah memiliki instrument dalam bentuk informasi produk dan layanan yang mampu mempengaruhi sudut pandang dan preferensi masyarakat dalam menentukan alternatif pembiayaan modal bagi pengembangan usaha pelaku pariwisata. Bank Syariah dalam penyaluran dana kepada para pelaku industri pariwisata halal juga berperan sebagai alat penyelesaian sengketa. Dimana Bank syariah sebagai alternatif pembiayaan bagi para pelaku usaha yang memiliki kendala modal dalam mengembangkan usahanya. Secara tidak langsung, peran Bank Syariah dalam mengembangkan industri pariwisata telah mencakup keseluruhan dimensi peran. Jika dikaitkan dengan peran pokok bank syariah dalam tinjauan berbagai aspek, bank syariah dalam pengembangan pariwisata halal berperan sebagai pemberdaya ekonomi umat. Bank syariah bertujuan untuk menyalurkan dana kepada para pelaku industri pariwisata halal, sehingga dapat berkembang dan berdaya serta meningkat kesejahteraan ekonominya. 


\section{DAFTAR PUSTAKA}

Disbudpar.aceh.prov.go.id (2016). Sekilas Tentang Wisata Halal. http://disbudpar.acehprov.go.id/sekilas-tentang-wisata-halal/. diakses tanggal 20 Oktober 2018

Fauzi, A. K., Astini, Y., Kartika, S. E., (2018). Peran Lembaga Keuangan Syariah dan Hotel Dalam Meningkatkan Potensi Wisata Halal Pulau Lombok. Jurnal Istinbath, 17(2), 451-475.

Firdhaus, Fadhli. (2018). Analisis Perencanaan Komunikasi Dinas Kebudayaan dan Pariwisata Provinsi Aceh dalam Mempromosikan Wisata Halal di Aceh. Skripsi. Fakultas Dakwah dan Komunikasi. Universitas Islam Negeri Ar-Raniry. Banda Aceh

Ilyas, Musyfikah. (2017). Sertifikasi Dan Labelisasi Produk Halal Perspektif Maslahat. Jurnal Al-Qadau: Peradilan dan Hukum Keluarga Islam. 4(2).

Kompasiana. (2017). 3 Peran Penting UMKM. Penggerak Penting Ekonomi Indonesia.

https://www.kompasiana.com/hikhman/599eabfae728e442d60622e2 /3-peran-penting-umkm-penggerak-penting-ekonomi-indonesia.

Diakses 22 November 2019

Muhammad, Iqbal Fadli. (2019). Pola Hubungan Pembiayaan Bank Syariah Terhadap Peningkatan Jumlah Wisatawan Religi/Halal \& Pertumbuhan PAD. Jurnal i-Finance. 5(1).

Novitasari, Maya. (2019). Optimalisasi Potensi Perbankan Syariah di Indonesia Bagi UMKM Halal Dalam Mendukung Sustainable Development Goals. Jurnal unipasby. 24(1).

Redaksi (2019). Kadisbudpar Aceh: Kunjungan Wisatawan ke Aceh terus meningkat. https:// beritakini.co/news/kadisbudpar-aceh-kunjunganwisatawan-ke-aceh-terus-meningkat/index.html. diakses tanggal 19 November 2019

Sedarmayanti. (2013). Manajemen Sumber Daya Manusia. Bandung: Refika Aditama.

Serambinews.com (2017). Market Share Perbankan Syariah di Aceh lebih 50\%. https://aceh.tribunnews.com /2017/09/06/market-shareperbankan-syariah-di-aceh-lebih-50. diakses tanggal 28 November 2019

Setiawan, A. E. (2020). Optimalisasi Peran Perbankan Syariah Dalam Mengembangkan Industri Halal (Studi Pada Industri Fashion Busana Muslim di Provinsi Lampung) (Doctoral dissertation, UIN Raden Intan Lampung).

Sidharta, Raden Bagus Faizal Irany. (2017). Optimalisasi Peran Perbankan Syariah Dalam Mendukung Wisata Halal. Jurnal Distribusi Universitas Mataram. 5(2).

Soebagyo. (2012). Strategi Pengembangan Pariwisata di Indonesia. Jurnal Penelitian Liquidity. 1(2), 153-158.

Sunaryo, Bambang. (2013). Kebijakan Pembangunan Destinasi Pariwisata Konsep dan Aplikasinya di Indonesia. Yogyakarta: Gava Media. 
Sungkawaningrum, F., \& Nasrullah, A. (2019). Eksplorasi Peran Perbankan Syariah Dalam Memajukan Industri Halal Di Sektor Makanan Halal. Wahana Islamika: Jurnal Studi Keislaman, 5(2), 32-48.

Sriprasert, Chainin, \& Rahman. (2014). Understnading Behavior and Needs of Halal Tourism in Andaman Gulf of Thailand: A Case of Asian Muslim. Journal of Advanced management Science. 2(3). 216-219.

Sterren, J.V. (2008). Financial Markets, Microfinance and Tourism in Developing Countries. Journal International Econommic NHTV Breda university of Applied Sciences, Breda, The Netherland, 35-44.

Wulandari, Vivin dan Deky Anwar. (2019). Analisis Pengaruh Dana Pihak Ketiga dan Pembiayaan Terhadap Market Share Perbankan Syariah di Indonesia Melalui Aset Sebagai Variabel Intervening. Jurnal Serambi, 1(1), 33-44

Yustati, H dan Handayani, L.D (2017). Strategi Perbankan Syariah dalam Menyokong Indonesia Menjadi Trend Setter Industri Halal. Jurnal Baabu Al-Ilmi: Ekonomi dan Perbankan Syariah, 2(1), 2527-4163. 